Technical Note / Nota Técnica

\title{
ANALYTICAL PERFORMANCE OF MICROWAVE-ASSISTED SOLVENT EXTRACTION (MASE) FOR THE ROUTINE DETERMINATION OF PAHS IN POLLUTED SOILS BY GAS CHROMATOGRAPHIC-MASS SPECTROMETRY (GC-MS)
}

\author{
José Enrique SÁNCHEZ-URÍA ${ }^{1 *}$ and Estela DEL CASTILLO-BUSTO²
}

${ }^{1}$ Departamento de Química Física y Analítica, Universidad de Oviedo, Julián Clavería 8, E33006 Oviedo, España

${ }^{2}$ Département Biomédical et Chimie Inorganique, Laboratoire National de Métrologie et d'Essais, 1, Rue Gaston Boissière, 76724 Paris Cedex 15, France

*Author for correspondence; jesu@uniovi.es

(Received January 2016; accepted August 2017)

Key words: pollutants, analysis, method, solid, samples

\begin{abstract}
The extraction of polycyclic aromatic hydrocarbons (PAHs) from polluted soil samples using microwave-assisted solvent extraction (MASE) with subsequent determination by gas chromatography-mass spectrometry (GC-MS) was investigated. The optimum conditions for the extraction were established and, after cleansing the extracts, pollutants were quantified by GC-MS. The detection limits for the 16 USEPA members of the family, analysis time, precision and linear range of the analysis were also established. The proposed extraction methodology was compared with the most conventional Soxhlet extraction technique, and validated by applying MASE to a reference soil sample. Good recoveries for the majority of PAHs (when the calibrations were carried out by using internal standards), a significant shortening of the time of analysis and the volume-reduction of solvent used were observed. Therefore, the MASE sample preparation methodology is a very good alternative to the extraction of PAHs from soil samples before final determination by GC-MS.
\end{abstract}

Palabras clave: contaminantes, análisis, método, muestras sólidas

\section{RESUMEN}

Se investiga la extracción de hidrocarburos aromáticos policíclicos (HAP) de muestras de suelo utilizando extracción con solventes asistida por microondas (MASE) y la posterior determinación de contaminantes mediante cromatografía de gases con detección de espectrometría de masas (GC-MS). Se establecieron las condiciones óptimas para la extracción y tras la limpieza de los extractos, los contaminantes fueron cuantificados por GC-MS. Se establecieron los límites de detección para los 16 miembros de la familia según la clasificación de la USEPA, el tiempo de análisis, la precisión y el rango dinámico lineal. Se comparó la metodología de extracción propuesta con el método convencional Soxhlet y se evaluó el método que se propone, aplicándolo a una muestra de suelo de referencia. Se obtuvieron buenas recuperaciones para la mayoría de los HAP (cuando las calibraciones se realizaban mediante patrón interno) 
y se observó una importante reducción del tiempo de análisis así como del volumen de solvente utilizado. Se demostró que la metodología de preparación de muestras de suelo mediante MASE es una buena alternativa para la extracción de HAP antes de la determinación por GC-MS.

\section{INTRODUCTION}

Polycyclic aromatic hydrocarbons (PAHs) are ubiquitous and persistent contaminants of anthropogenic origin affecting a given ecosystem. Waters, soils and sediments are the receivers in the last instance of such pollutants coming from a contaminated atmosphere (where they accumulate as a result of the incomplete combustion of coal, oil and wood) (Wilde and Jones 1995). The heaviest compounds are quickly condensed or adsorbed onto particles and then they fall to the ground or into surface waters (including wet or dry deposition), industrial effluents (Moore and Ramamoorthy 1994) or municipal wastewater (Manoli and Samara 1999). As result of the hydrophobic characteristic of PAHs, their water solubility is very low when they appear in water adsorbed on suspended particles (Mahafley et al. 1988). The mobility in the soil-plant system also seems to be very slow.

PAHs are regarded as persistent organic pollutants in the environment with mutagenic and carcinogenic properties, and they have been included on the USEPA and European Union lists of pollutants (Bouzige et al. 1999). The USEPA has identified 16 PAHs as priority pollutants, some of which are considered as probable human carcinogens. On the other hand, the European list contains eight target PAHs, including benzo(a)anthracene, chrysene, dibenzo(a,h)anthracene, benzo(a) pyrene, benzo(k)fluoranthene, benzo(g,h,i)perylene, and indeno(1,2,3-cd)pyrene (Menzie et al. 1992).

The extraction of PAHs from contaminated soils for their analysis can be achieved using a number of well-established methods wherein Soxhlet extraction (USEPA 1986, Lara-Gonzalo 2015) is the most conventional method. This sample preparation technique is rather time consuming (12-24 h), with the additional drawbacks of high solvent consumption as well as energy demand. Therefore, alternative extraction techniques have been developed including sonication (Cejpeck et al. 1995), ultrasonic micellar extraction (Pino et al. 2001), supercritical fluid extraction (Librando et al. 2004), accelerated solvent extraction (Richer et al. 1996), pressurized hot water extraction (Andersson et al. 2002), and microwave assisted solvent extraction (MASE) (Letellier and Budzinski 1999a). A comparative study of several extraction methods for
PAHs in contaminated soils was carried out by Song et al. (2002), concluding that no significant differences in the extraction efficiency of the methods had been observed for less polluted soils.

From the first publication about the use of microwave energy (Ganzler et al. 1986) to enhance the extraction of organic compounds from solid samples, different oven designs have been used for such purpose. In fact, domestic microwave ovens were initially used in laboratories, while today a number of manufacturers supply microwave ovens specially designed for MASE analytical applications with high security features.

In the present study, the determination of PAHs by gas chromatography-mass spectrometry (GC-MS) in polluted soils is attempted by using the MASE system Ethos Sel ${ }^{\circledR}$ Microwave Labstation (Milestone, CT, USA). This extraction system has several advantages over the more conventional system: it allows the use of pure non-polar solvents (as hexane) with low microwave power by using a magnetic stirring of "weflon" (fluoropolymer that absorbs microwave energy), continuous control of the temperature and power supply into the vessel, detection of organic vapor in the microwave cavity, self-close action when the vessel is open by overpressure and a vacuum system allowing for fast filtration of extracts and solvent evaporation after extraction. The equipment allows for rapid extraction of such analytes from the soil samples, and rapid filtration of extracts and the evaporation of solvents in a single microwave unit, prior to the final cleaning and sample solution reconstitution for the final injection into the GC-MS.

\section{MATERIALS AND METHODS}

\section{Chemical and reagents}

A primary mixture standard solution with a concentration of $2000 \mu \mathrm{g} / \mathrm{mL}$ of each component of the 16 PAHs in a benzene/dichloromethane mix from AccuStandard was used. Deuterated internal standards (IS) containing naftalene- $\mathrm{d}_{8}$, acenaphtene- $\mathrm{d}_{10}$, phenantrene- $\mathrm{d}_{10}$, chrysene- $\mathrm{d}_{12}$, and perylene- $\mathrm{d}_{12}$ each at $4000 \mu \mathrm{g} / \mathrm{mL}$ in dichloromethane were obtained from Hewlett-Packard. 
The secondary mixture standard solution $(20 \mu \mathrm{g} / \mathrm{mL}$ for each of the 16 PAHs) was prepared by the dilution of $1 \mathrm{~mL}$ of the PAH primary mixture to $100 \mathrm{~mL}$ with hexane. This solution was stored in a refrigerator in brown glass bottles and in the dark. A second solution $(40 \mu \mathrm{g} / \mathrm{mL})$ of IS was also prepared by dilution of 1 $\mathrm{mL}$ of a commercial solution of IS to $100 \mathrm{~mL}$ with hexane. Finally, calibration solutions were prepared by weight from different amounts of the secondary standard solution of the 16 PAHs, $40 \mu \mathrm{L}$ of $40 \mu \mathrm{g} / \mathrm{mL}$ IS standard solution, being the final volume $1.5 \mathrm{~mL}$. The PAH concentration of the calibration solutions ranged between $0.10 \mu \mathrm{g} / \mathrm{mL}$ and $1.95 \mu \mathrm{g} / \mathrm{mL}$. These solutions were prepared at the moment of calibration.

High purity chromatographic quality hexane, acetone and dichloromethane were used. The validation of the methodology was carried out by the analysis of a certified soil (CRM-104-100 [LGC Promochem]) with PAH levels 0.77 and $24.8 \mathrm{mg} / \mathrm{kg}$.

\section{Instrumentation}

A Hewlett-Packard (Palo Alto, CA, USA) model 6890 gas-chromatograph coupled to a HewlettPackard 5973 mass spectrometric detector working in single ion monitoring mode (SIM) were used for PAHs analytical separation and detection with an automatic injection system 7683 from Hewlett-Packard.

The GC separation column was a $30 \mathrm{~m} \times 0.33 \mathrm{~mm}$ i.d. $\times 25 \mu \mathrm{m}$ thin thickness DB-XLB (equivalent to $5 \%$ phenyl, $95 \%$ methylpolysiloxane) fused silica capillary column (Hewlett- Packard). An electronic pressure control was utilized to maintain a constant gas carrier helium flow of $1.0 \mathrm{~mL} / \mathrm{min}$ throughout the oven program. The injector and detector port temperatures were 300 and $230{ }^{\circ} \mathrm{C}$, respectively. The oven program temperature was $60^{\circ} \mathrm{C}$ (hold $1.5 \mathrm{~min}$ ), rate $8^{\circ} \mathrm{C} / \mathrm{min}$ to $270{ }^{\circ} \mathrm{C}$ (hold $10 \mathrm{~min}$ ), and rate $5{ }^{\circ} \mathrm{C} /$ min to $280{ }^{\circ} \mathrm{C}$ (hold $13 \mathrm{~min}$ ). Split mode was used.

The mass spectrometric detector was operated in electron ionization mode (EI) with ionization energy of $70 \mathrm{eV}$; the source and quadrupole temperatures were 230 and $150^{\circ} \mathrm{C}$, respectively; the dwell time was $100 \mathrm{~ms}$ for all the ions.

A Milestone Ethos Sel was used for microwaveassisted organic extraction. This device is furnished with accessories for filtration (FilterEx-12), evaporation (EvaporEx-12) and software (Easywave), and the microwave oven incorporates a vacuum system (Milestone Vac 2000).

Several special materials for microwaves, e.g. Teflon pumps, microfilters, vials for filtration, weflon stirrers, etc., were provided for the Milestone Ethos Sel. A system for Soxhlet extraction (Selecta, Spain), a vacuum manifold (Whatman, Middlesex, England) and a rotatory evaporator (Heidolph, Nüremberg, Germany) were also used.

\section{Separation of different PAHs by gas chromatog- raphy and mass spectrometry detection}

By using a standard sample of PAHs containing the 16 USEPA pollutants, chromatographic separation was carried out with the internal standard (IS) technique in order to correct any possible instrumental drift. The deuterated homologous of PAHs (naftalene- $\mathrm{d}_{8}$, acenaphtene- $\mathrm{d}_{10}$, phenantrene- $\mathrm{d}_{10}$, chrysene- $\mathrm{d}_{12}$, and perylene- $\mathrm{d}_{12}$ ) were used as IS. These compounds are not present in real samples, and they have physical and chemical properties similar to those analytes providing interference-free GC-MS signals.

The mass-spectrum of perfluorotributylamine was used for a wide mass-calibration range. Detection was carried out using the selection ion monitorization (SIM) mode, by measuring only the $\mathrm{m} / \mathrm{z}$ ratio of the most abundant molecular fragments.

Table I shows retention times of the main and secondary ions of PAH and internal standards monitored, selected for each ion.

TABLE I. RETENTION TIMES AND MAIN AND SECONDARY IONS OF PAHs AND INTERNAL STANDARDS MONITORED SELECTED FOR EACH ION

\begin{tabular}{clcc}
\hline $\begin{array}{c}\text { Retention } \\
\text { times (min) }\end{array}$ & Compound & $\begin{array}{c}\text { Main } \\
\text { ion }\end{array}$ & $\begin{array}{c}\text { Secondary } \\
\text { ion }\end{array}$ \\
\hline 10.59 & Naphtalene d-8 & 136 & ---- \\
10.65 & Naphtalene & 128 & 129 \\
15.52 & Acenaphthylene & 152 & 153 \\
15.98 & Acenaphthene d-10 & 164 & ---- \\
16.77 & Acenaphthene & 154 & 153 \\
17.76 & Fluorene & 166 & 165 \\
20.68 & Phenanthrene d-10 & 188 & ---- \\
20.75 & Phenanthrene & 178 & 179 \\
20.95 & Anthracene & 178 & 179 \\
24.55 & Fluoranthene & 202 & 101 \\
25.24 & Pyrene & 202 & 101 \\
29.19 & Benzo (a) anthracene & 228 & 226 \\
29.25 & Chrisene d-12 & 240 & ---- \\
29.35 & Chrisene & 228 & 226 \\
35.03 & Benzo (b) fluoranthene & 252 & 253 \\
35.87 & Benzo (k) fluoranthene & 252 & 253 \\
37.34 & Benzo (a) pyrene & 252 & 253 \\
37.81 & Perylene d-12 & 264 & ---- \\
46.97 & Indene (1,2,3-cd) pyrene & 276 & 138 \\
47.14 & Dibenzo (a,h) anthrathene & 278 & 139 \\
49.80 & Benzo (g,h,i) perylene & 276 & 138 \\
\hline
\end{tabular}


Extraction, filtration and preconcentration of PAHs from the soil samples procedure

The extraction of 16 PAHs from soil samples was carried out in the Milestone Ethos Sel microwave oven. One of the 12 vessels, with the same volume of solvent as the samples, was aimed at measuring the applied temperature. The vial of filtration belonging to each vessel was of use to test a microfilter, a performance disc (for microfilter scaling), a coated magnet on quartz and the base of the vial made from weflon. Two grams $(2.0000 \mathrm{~g})$ of sample soil were weighed and deposited in the filtration vial and then $25 \mathrm{~mL}$ of a hexane/acetone 1:1 mixture was added to the filtration vial allowing $10 \mathrm{~mL}$ of the mixture to remain in the extraction vessel. Then the extraction vessels were opened, the microwave power was set to $500 \mathrm{~W}$, the stirring to $100 \%$ and the system was started following the optimized program. A temperature of $120^{\circ} \mathrm{C}$ was selected in two steps, a first step from room temperature to $120{ }^{\circ} \mathrm{C}$ for $10 \mathrm{~min}$, and then temperature was maintained for another $10 \mathrm{~min}$.

When the extraction program was finished and temperature was lower than $40{ }^{\circ} \mathrm{C}$ (after approximately $20 \mathrm{~min}$ ), the filtration vessels were opened and the filtration was carried out using the FilterEx-12 system by connecting the vacuum pump. After filtration, the vials were coupled to the EvapEx-12 evaporation system and this set was introduced into the oven. Then, the microwave power was tuned to $135 \mathrm{~W}$, while a vacuum was applied simultaneously. In 14.5 min the volume was reduced to $2 \mathrm{~mL}$. This extract was cleansed by solid phase extraction (SPE) using two coupled silica gel cartridges, previously conditioned with hexane. The PAHs were retained there and they were eluted by $5 \mathrm{~mL}$ (two times) of a hexane/acetone 7:3 mixture. This extract was pre-concentrated again to $2 \mathrm{~mL}$ by evaporation (applying the vacuum commercial system to $135 \mathrm{~W}$ of power during $12 \mathrm{~min}$ ). After the adequate addition of internal standards and apposite dilutions ( 1 preconcentrate: 1 hexane) dilution for naphthalene, acenaphthylene, acenaphthene, fluorene, and dibenzo(a,h)anthracene determination; (1 preconcentrate:10 hexane) dilution for phenanthrene, anthracene, pyrene, venzo(a)anthracene, indene $(1,2,3-\mathrm{cd})$ pyrene, and venzo(g,h,i)perylene determination; and (1 preconcentrate:50 hexane) dilution for fluorantene, chrysene, venzo(b,k)fluorantene, and venzo(a)pyrene determination, the resulting treated and diluted sample solutions were injected in the gas chromatograph.

\section{RESULTS AND DISCUSSION}

\section{Optimization of the microwave-assisted solvent extraction}

The optimum experimental parameters for the extraction of PAHs by MASE were investigated by using a sample soil contaminated with these pollutants.

\section{Extraction temperature}

Temperatures of $80,100,115,120,120^{*}$ and $130 *{ }^{\circ} \mathrm{C}$ were selected according to the literature (López-Ávila et al. 1994, Barnabas et al. 1995, Chee et al. 1996). The asterisks mean that in such cases the applied temperature program was carried out as follows: a first step from room temperature to final temperature $(10 \mathrm{~min})$ and then the final temperature was maintained for $10 \mathrm{~min}$. The rest of the parameters (extraction time, volume of the solvent and solvent) were maintained constantly.

Table II shows the concentrations for the 16 studied PAHs according to the applied temperatures with the exception of dibenzo(a,h)anthracene. As can be seen, for PAHs containing 2-4 aromatic rings, better extraction conditions were obtained by applying the extraction program in two steps at $120^{*} \mathrm{C}$, being $100^{\circ} \mathrm{C}$ the best option for PAHs with 5-7 aromatic rings. In subsequent studies, we selected a temperature of $120^{*}{ }^{\circ} \mathrm{C}$ in two steps, as a compromise solution. This temperature allows for the extraction of higher amounts of most PAHs, especially the most volatile ones (with lower molecular mass), which can be found in soils at lower concentrations.

\section{Extraction time}

A extraction temperature of $120^{\circ} \mathrm{C}(*)$ in two steps was selected (first, from room temperature to $120^{\circ} \mathrm{C}$ in 10 min for all cases, and a second step at $120^{\circ} \mathrm{C}$ for $5,10,15$ and $20 \mathrm{~min}$ ), and the same parameters referred in the previous paragraph were maintained constantly. The obtained results are shown in table III. As can be seen, similar considerations as those formulated in the study of temperature can be applied: for compounds having 2-4 aromatic rings in their molecule, the optimum extraction time was $20 \mathrm{~min}$ at $120^{\circ} \mathrm{C}$, but for PAHs with 5-7 aromatic rings, the time was $15 \mathrm{~min}$, although differences of concentrations for both times are not significant as has been mentioned in the literatures. Budzinski et al. (1999) and Letelier and Budzinski (1999b) have in mind the same criterion for the study of the temperature. A compromise solution of $20 \mathrm{~min}$ as extraction time in the second step was selected. 


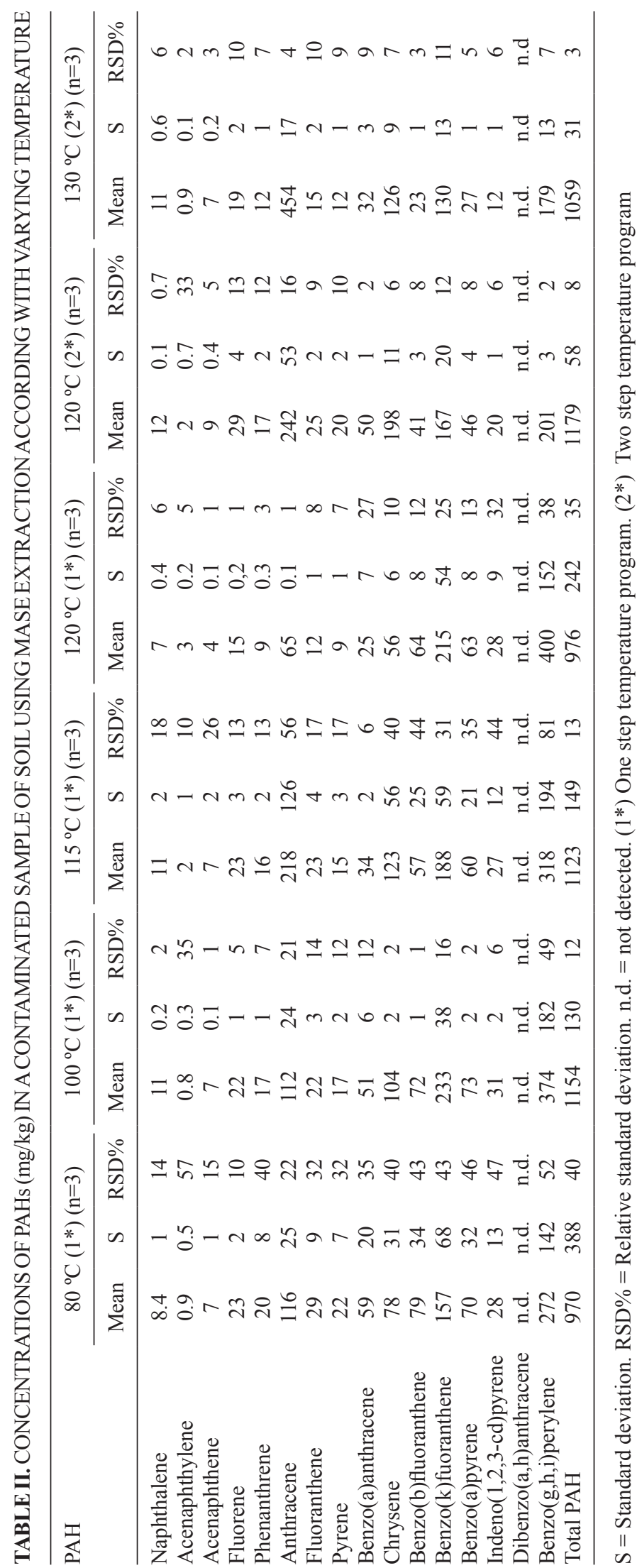


TABLE III. CONCENTRATIONS OF PAHs ( $\mathrm{mg} / \mathrm{kg}$ ) IN A CONTAMINATED SAMPLE OF SOIL USING THE MASE EXTRACTION WITH VARYING TIMES

\begin{tabular}{|c|c|c|c|c|c|c|c|c|c|c|c|c|}
\hline \multirow[t]{2}{*}{ PAH } & \multicolumn{3}{|c|}{$15 \min (n=3)$} & \multicolumn{3}{|c|}{$20 \min (n=3)$} & \multicolumn{3}{|c|}{$25 \min (n=3)$} & \multicolumn{3}{|c|}{$30 \min (n=3)$} \\
\hline & Mean & $\mathrm{S}$ & $\mathrm{RSD} \%$ & Mean & $\mathrm{S}$ & $\mathrm{RSD} \%$ & Meab & $\mathrm{S}$ & $\mathrm{RSD} \%$ & Mean & $\mathrm{S}$ & $\mathrm{RSD} \%$ \\
\hline Naphthalene & 12.4 & 1.5 & 11.8 & 12.2 & 0.1 & 0.7 & 12.2 & 0.3 & 2.1 & 12.1 & 0.5 & 4.5 \\
\hline Acenaphthylene & 0.5 & 0.3 & 72 & 2.1 & 0.7 & 12.2 & 0.3 & 2.1 & 12.1 & 21 & 0.5 & 4.5 \\
\hline Acenaphthene & 7.6 & 0.5 & 6.2 & 8.6 & 0.4 & 4.9 & 9.2 & 0.7 & 7.2 & 8.7 & 0.3 & 4.0 \\
\hline Fluorene & 23.5 & 1.1 & 4.8 & 29 & 4 & 13 & 26 & 1.3 & 4.9 & 28 & 7 & 25 \\
\hline Phenanthrene & 16.3 & 0.5 & 3.3 & 17 & 2 & 12 & 16 & 2 & 13 & 15 & 3 & 21 \\
\hline Anthracene & 219 & 124 & 57 & 342 & 53 & 16 & 314 & 17 & 5 & 270 & 10 & 4 \\
\hline Fluoranthene & 24 & 2 & 8 & 25 & 2 & 9 & 25 & 3 & 13 & 22 & 3 & 15 \\
\hline Pyrene & 18.6 & 1.7 & 9 & 20 & 2 & 10 & 10 & 2 & 12 & 17 & 3 & 16 \\
\hline Benzo(a)anthracene & 53 & 10 & 19 & 50 & 1.2 & 2.3 & 49 & 7 & 12 & 27 & 11 & 42 \\
\hline Chrysene & 108 & 39 & 36 & 190 & 11 & 6 & 172 & 31 & 18 & 116 & 26 & 22 \\
\hline Benzo(b)fluoranthene & 56 & 23 & 42 & 41 & 3 & 8 & 39 & 1.5 & 4 & 38 & 3 & 9 \\
\hline Benzo(k)fuoranthene & 160 & 26 & 18 & 167 & 20 & 12 & 177 & 8 & 3 & 157 & 25 & 16 \\
\hline Benzo(a)pyrene & 57 & 14 & 25 & 45 & 4 & 8 & 45 & 4 & 8 & 43 & 3 & 7 \\
\hline Indeno(1,2,3-cd)pyrene & 23 & 4 & 19 & 20 & 1.2 & 6.2 & 20 & 0.9 & 4.5 & 20 & 3 & 14 \\
\hline Dibenzo(a,h)anthracene & n.d. & n.d. & n.d. & n.d. & n.d. & n.d. & n.d. & n.d. & n.d. & n.d. & n.d. & n.d. \\
\hline Benzo(g,h,i)perylene & 353 & 40 & 11 & 201 & 3 & 2 & 207 & 18 & 9 & 215 & 29 & 13 \\
\hline Total PAH & 1143 & 144 & 13 & 1179 & 58 & 5 & 1124 & 61 & 5 & 991 & 62 & 6 \\
\hline
\end{tabular}

$\mathrm{S}=$ Standard Deviation. $\mathrm{RSD} \%=$ Relative standard deviation. n.d. $=$ not detected

\section{Volume of solvent}

The volume of solvent used for MASE is another parameter that has an effect on the extraction of PAHs from soil samples. In order to analyze its influence on the extraction of analytes by using an hexane/acetone 1:1 mixture as extraction solvent, several volumes $(20,25,30$, and $35 \mathrm{~mL})$ of such mixture were used under two conditions: (1) the volume of solvent must be enough to cover the soil sample and (2) $10 \mathrm{~mL}$ of this volume must be added to the extraction vessel to secure the direct contact of the sensor with the solution, and the rest 10, 15, 20 and $25 \mathrm{~mL}$ should be added to the filtration vial. The capacity of the vials $(26 \mathrm{~mL})$ limits the use of a higher volume. Obviously, for the reduction to a final volume of $2 \mathrm{~mL}$ by using microwave energy (135 W) and vacuum together, different time lapses must be applied: $12 \mathrm{~min}$ for $20 \mathrm{~mL}, 14.5 \mathrm{~min}$ for $25 \mathrm{~mL}, 17$ min for $30 \mathrm{~mL}$ and $20 \mathrm{~min}$ for $35 \mathrm{~mL}$. During this study, the rest of the parameters remained constant: $2.0000 \mathrm{~g}$ of contaminated soil, $120{ }^{\circ} \mathrm{C}$ as extraction temperature in two steps: 20 min as extraction time, $500 \mathrm{~W}$ for the microwave power supply, stirring 100 $\%$ and $20 \mathrm{~min}$ as a final cooling step. Table IV shows the concentrations of PAHs found on the sample soil when different volumes of solvent mixture were used for the extraction. Again, slight differences in concentration values for different volumes of solvent were observed, thus it can be said that the volume of solvent is not an important factor for the extraction of PAHs from soil samples, as has been previously mentioned (Barnabas et al. 1995, Chee et al. 1996). For subsequent experiments, a volume of $25 \mathrm{~mL}$ of a hexane/acetone 1:1 mixture, added into the filtration vial, was selected as the optimum alternative for the majority of PAHs.

\section{Choice of solvent}

Acetone has been recommended as a more suitable solvent than hexane for the extraction of PAHs from soil samples (Barnabas et al. 1995). The acetone molecule has a permanent dipole that can induce dipole-dipole interactions with numerous $\pi$-type electrons from PAHs. On the other hand, hexane is a non-polar solvent, which means that it is unable to generate such interactions. We have analyzed whether there is a difference between using a mixture of hexane/acetone and acetone alone for the extraction. Once the previous parameters were optimized, the results obtained by using the hexane/acetone mixture were compared with those obtained by using acetone with the same purposes. In this case, the constant parameters were $20 \mathrm{~min}$ as extraction time, $500 \mathrm{~W}$ for the microwave power supply, stirring $100 \%$ and $20 \mathrm{~min}$ as a final cooling step. The results obtained are shown in table $\mathbf{V}$, where we can verify that the 
TABLE IV. CONCENTRATIONS OF PAHs ( $\mathrm{mg} / \mathrm{kg}$ ) IN A CONTAMINATED SAMPLE OF SOIL USING THE MASE EXTRACTION ACCORDING TO VOLUME OF SOLVENT SELECTED

\begin{tabular}{|c|c|c|c|c|c|c|c|c|c|c|c|c|}
\hline \multirow[t]{2}{*}{ PAH } & \multicolumn{3}{|c|}{$\begin{array}{c}20 \text { mL Hexane/Acetone } \\
(1: 1) \quad(\mathrm{n}=3)\end{array}$} & \multicolumn{3}{|c|}{$\begin{array}{c}25 \mathrm{~mL} \text { Hexane/Acetone } \\
(1: 1) \quad(\mathrm{n}=3)\end{array}$} & \multicolumn{3}{|c|}{$\begin{array}{c}30 \mathrm{~mL} \text { Hexane/Acetone } \\
(1: 1) \quad(\mathrm{n}=3)\end{array}$} & \multicolumn{3}{|c|}{$\begin{array}{c}35 \mathrm{~mL} \text { Hexane/Acetone } \\
(1: 1) \quad(\mathrm{n}=3)\end{array}$} \\
\hline & Mean & $\mathrm{S}$ & RSD $\%$ & Mean & $\mathrm{S}$ & $\mathrm{RSD} \%$ & Meab & $\mathrm{S}$ & $\mathrm{RSD} \%$ & Mean & $\mathrm{S}$ & RSD\% \\
\hline Naphthalene & 12.4 & 0.7 & 5.6 & 12.2 & 0.1 & 0.7 & 14 & 3 & 10 & 12.4 & 0.3 & 2.5 \\
\hline Acenaphthylene & 0.4 & 0.1 & 32 & 2.1 & 0.7 & 32 & 0.5 & 0.1 & 16 & 1.1 & 0.7 & 60 \\
\hline Acenaphthene & 8.5 & 0.3 & 2.1 & 8.6 & 0.4 & 4.9 & 8.2 & 0.3 & 4.1 & 9.4 & 6.4 & 4.4 \\
\hline Fluorene & 23 & 0.5 & 2 & 29 & 4 & 13 & 25 & 0.9 & 3.7 & 24 & 1 & 4 \\
\hline Phenanthrene & 14.5 & 1.0 & 6.8 & 17 & 2 & 12 & 17 & 5 & 29 & 17 & 3 & 9 \\
\hline Anthracene & 328 & 18 & 6 & 342 & 53 & 16 & 274 & 21 & 8 & 200 & 81 & 41 \\
\hline Fluoranthene & 21 & 2 & 8 & 25 & 2 & 9 & 23 & 4 & 16 & 23 & 3 & 12 \\
\hline Pyrene & 16.5 & 1.3 & 7.7 & 20 & 2 & 10 & 18 & 3 & 14 & 18 & 2 & 13 \\
\hline Benzo(a)anthracene & 45.2 & 1 & 2 & 50 & 1.2 & 2.3 & 39 & 6 & 18 & 49 & 12 & 20 \\
\hline Chrysene & 142 & 7 & 5 & 206 & 12 & 6 & 137 & 14 & 10 & 126 & 40 & 12 \\
\hline Benzo(b)fluoranthene & 29 & 3 & 10 & 41 & 3 & 8 & 36 & 6 & 17 & 35 & 5 & 14 \\
\hline Benzo(k)fuoranthene & 177 & 21 & 12 & 176 & 20 & 12 & 214 & 43 & 23 & 187 & 7 & 4 \\
\hline Benzo(a)pyrene & 38 & 4 & 10 & 46 & 4 & 8 & 46 & 8 & 17 & 44 & 4 & 9 \\
\hline Indeno(1,2,3-cd)pyrene & 16 & 0.3 & 1.7 & 20 & 1.2 & 6.2 & 19 & 2 & 13 & 17 & 2 & 12 \\
\hline Dibenzo(a,h)anthracene & n.d. & n.d. & n.d. & n.d. & n.d. & n.d. & n.d. & n.d. & n.d. & n.d. & n.d. & n.d. \\
\hline Benzo(g,h,i)perylene & 283 & 24 & 8 & 200 & 3 & 2 & 264 & 44 & 12 & 306 & 32 & 10 \\
\hline Total PAH & 1154 & 7 & 1 & 1193 & 58 & 5 & 1135 & 106 & 9 & 1068 & 128 & 12 \\
\hline
\end{tabular}

$\mathrm{S}=$ Standard deviation. $\mathrm{RSD} \%=$ Relative standard deviation. n.d. $=$ not detected

TABLE V. CONCENTRATIONS OF PAHs ( $\mathrm{mg} / \mathrm{kg}$ ) IN A CONTAMINATED SAMPLE OF SOIL USING THE MASE EXTRACTION WITH VARYING SOLVENTS

\begin{tabular}{|c|c|c|c|c|c|c|}
\hline \multirow[t]{2}{*}{ PAH } & \multicolumn{3}{|c|}{$\begin{array}{l}\text { Acetone } \\
(\mathrm{n}=3)\end{array}$} & \multicolumn{3}{|c|}{$\begin{array}{l}\text { Hexane/Acetone }(1: 1) \\
\qquad(\mathrm{n}=3)\end{array}$} \\
\hline & Mean & $\mathrm{S}$ & RSD $\%$ & Mean & $\mathrm{S}$ & $\mathrm{RSD} \%$ \\
\hline Naphthalene & 8.8 & 0.7 & 7.9 & 12.2 & 0.1 & 0.8 \\
\hline Acenaphthylene & 2.4 & 0.1 & 2.5 & 2.1 & 0.7 & 33 \\
\hline Acenaphthene & 6.8 & 0.1 & 0.7 & 8.6 & 0.4 & 4.9 \\
\hline Fluorene & 20 & 1.7 & 8.5 & 29 & 4 & 13 \\
\hline Phenanthrene & 15 & 2.0 & 3.0 & 17 & 2 & 12 \\
\hline Anthracene & 376 & 58 & 15 & 342 & 53 & 15 \\
\hline Fluoranthene & 21 & 2 & 8 & 25 & 2 & 9 \\
\hline Pyrene & 16.1 & 1.3 & 8.1 & 20 & 2 & 10 \\
\hline Benzo(a)anthracene & 64 & 23 & 36 & 50 & 1.2 & 2.4 \\
\hline Chrysene & 114 & 23 & 20 & 206 & 12 & 6 \\
\hline Benzo(b)fluoranthene & 26 & 3 & 12 & 41 & 3 & 7 \\
\hline Benzo(k)fuoranthene & 91 & 10 & 11 & 176 & 20 & 11 \\
\hline Benzo(a)pyrene & 31 & 1.4 & 4.5 & 46 & 4 & 9 \\
\hline Indeno(1,2,3-cd)pyrene & 16 & 2 & 13 & 20 & 1.2 & 6 \\
\hline Dibenzo(a,h)anthracene & n.d. & n.d. & n.d. & n.d. & n.d. & n.d. \\
\hline Benzo(g,h,i)perylene & 211 & 32 & 15 & 200 & 3 & 2 \\
\hline Total PAH & 1018 & 131 & 13 & 1193 & 58 & 5 \\
\hline
\end{tabular}

$\mathrm{S}=$ Standard deviation. $\mathrm{RSD} \%=$ Relative standard deviation. n.d. $=$ not detected 
mixture hexane/acetone is more suitable for PAHs extraction from soil samples, which agrees with prior research (López-Ávila et al. 1994, Chee et al. 1996).

\section{Analytical performance characteristics}

To evaluate the linearity of detector responses after MASE-GC-MS, standard solutions containing all 16 PAHs in a range of concentrations between 35 and 2000 $\mathrm{ng} / \mathrm{mL}$ were prepared. The results are summarized in table VI. For all PAHs, the responses were linear over the range tested, with regression coefficients better than $0.9940(n=3)$. The linear range was established by plotting the quotient area of the analytic/area of IS vs. the quotient concentration of analyte/concentration of IS. The limits of detection (LOD) and limits of quantification (LOQ) were calculated from equations defining calibration lines by measuring (by triplicate) three solutions containing 16 PAHs in very low concentrations (35, 155 and $254 \mathrm{ng} / \mathrm{mL})$ with the Long and Winefordner (1985) criterion. The values found were $10-32 \mathrm{ng} / \mathrm{mL}$ for LOD and 32-108 $\mathrm{ng} / \mathrm{mL}$ for LOQ, which shows that quantification should be possible for PAHs at levels found in soils and sediments (Popp et al. 1997, Saim et al. 1997, Schantz et al. 1997). Repeatability, which was evaluated for two levels of concentrations ( 155 and $531 \mathrm{ng} / \mathrm{mL}$ ), with and without IS, was satisfactory with standard relative deviations (RDS) between $1 \%$ and $6 \%$ if IS was employed.

The analytical advantages of the MASE-GC-MS procedure were previously evaluated in samples of polluted soil collected near a coke oven by comparing the observed results with those obtained for the PAHs of such samples previously extracted by using the classical Soxhlet method recommended by the USEPA(1995). In this latter method, the soil amount was $5.0000 \mathrm{~g}$, the volume of the solvent used was 350 $\mathrm{mL}$ of a 1:1 mixture of hexane/acetone, and the extraction time was 18 hours at the rate of 3-4 cycles per hour. The cleaning and pre-concentration of extracts were carried out by rotoevaporation-SFE-rotoevaporation. Then the cleaned extracts were analyzed by GC-MS. The results obtained for both PAHs extraction methods under scrutiny (MASE and Soxhlet) in mg of PAH $/ \mathrm{kg}$ of soil are shown in table VII. As can be seen, both extraction techniques provided similar values for the majority of PAHs with the exception of chrysene, benzo(b)fluoranthene and benzo(k)fluoranthene.

\section{Validation of the MASE method and real sample application}

In order to validate the proposed method, the new set-up was used to extract PAHs from the CRM 104100 soil. The reference material came from Elisabeth
River in the Chesapeake Bay, VA, USA, containing 16 PAHs (the values for benzo(k,b)fluoranthene and dibenzo(a,h)anthracene are only recommended). These two compounds of the reference material were extracted by both MASE and Soxhlet techniques.

Table VIII shows the certified values for different PAHs with their confidence limits; concentrations $(\mathrm{mg} / \mathrm{kg})$ of the pollutants obtained by the MASE and Soxhlet extraction methodologies; and recovery values for the different PAHs with final determination by GC-MS. In both cases, MASE and Soxhlet, we found that our values fall into the confidence limits established for the reference material. However, the recovery values obtained for PAHs turned out to be higher than those obtained with MASE (anomalous values were observed for fluoranthene $(-147 \%)$ and benzo(g,h)perylene $(-124 \%)$. Nevertheless, once clean extracts were obtained for the analysis by GC-MS, it was necessary to handle the extracts at three dilution levels: (1 preconcentrate: 1 hexane) dilution for naphthalene, acenaphthylene, acenaphthene, fluorene, and dibenzo(a,h)anthracene determination; (1 preconcentrate:10 hexane) dilution for phenanthrene, anthracene, pyrene, venzo(a) anthracene, indene(1,2,3-cd)pyrene, and venzo(g,h,i) perylene determination; and (1 preconcentrate:50 hexane) dilution for fluorantene, chrysene, venzo(b,k) fluorantene, and venzo(a)pyrene determination. The necessary dilutions are the main drawback of the GCMS determination, but they are necessary following both PAHs extraction methods.

Figure 1 shows the chromatogram of PAHs contained in the CRM104-100 soil extract using MASE as the extraction technique and 1:10 dilution.

\section{CONCLUSION}

This research demonstrated that microwaveassisted solvent extraction (MASE) was the best alternative for conventional sample preparation to extract PAHs from polluted soil samples for final GC-MS determinations. The main advantages of the proposed extraction technique for PAHs are: i) the smaller size of the sample ( $2 \mathrm{~g}$ for MASE vs. $5 \mathrm{~g}$ for Soxhlet); ii) substantial smaller volume of solvent extraction ( $25 \mathrm{~mL}$ for MASE vs. $350 \mathrm{~mL}$ for Soxhlet); iii) and substantial saving of time (40 min vs. $24 \mathrm{~h}$ ). Moreover, this technique allows for simultaneous operation of twelve samples. On the other hand, the validation results and limits of quantification achieved for all the PAHs by GCMS, after purification and pre-concentration of 


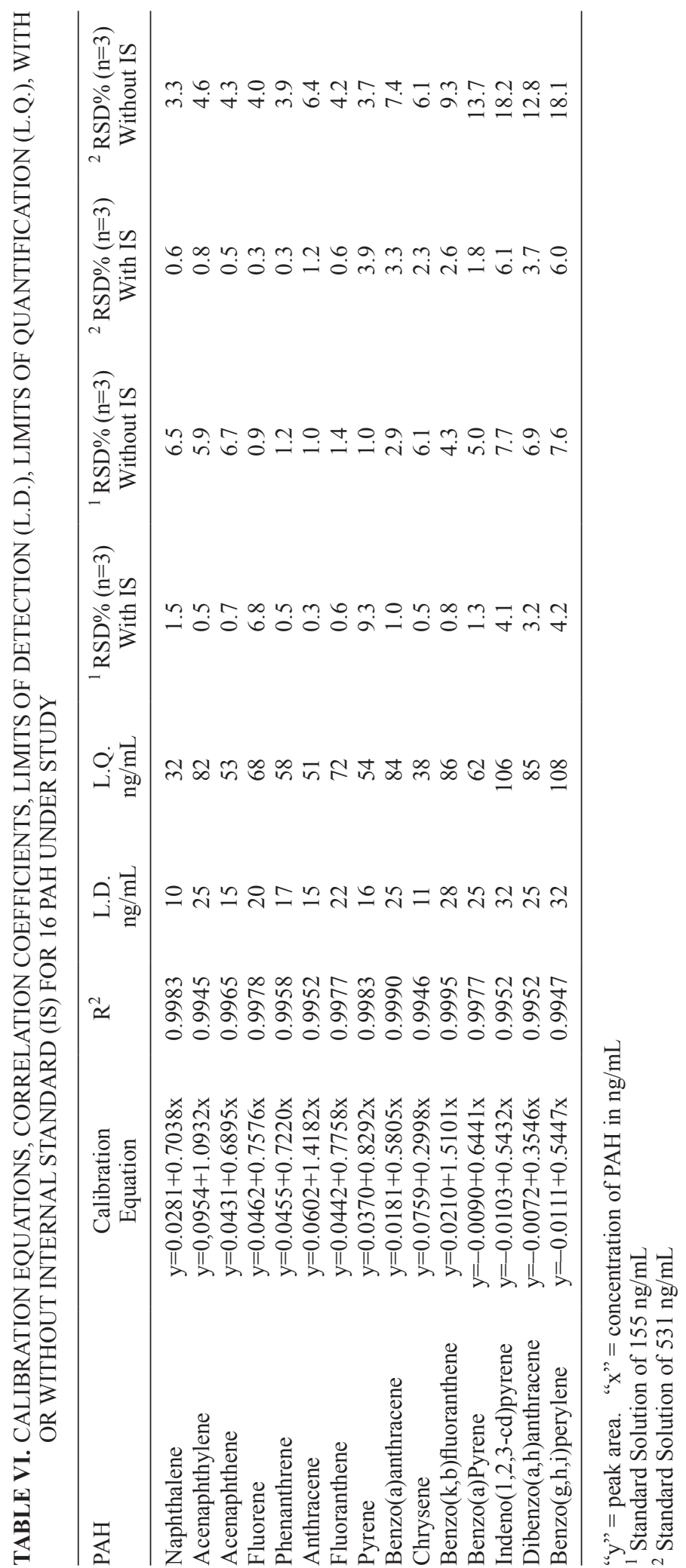


TABLE VII. MEASURED CONCENTRATIONS OF PAHs $(\mathrm{mg} / \mathrm{kg})$ IN A CONTAMINATED SAMPLE OF SOIL USING THE SOXHLET AND OPTIMIZED MASE EXTRACTIONS

\begin{tabular}{|c|c|c|c|c|c|c|c|}
\hline \multirow[t]{2}{*}{ PAH } & \multicolumn{4}{|c|}{$\begin{array}{l}\text { Soxhlet extraction } \\
\qquad n=3\end{array}$} & \multicolumn{3}{|c|}{$\begin{array}{c}\text { MASE } \\
n=3\end{array}$} \\
\hline & \multicolumn{2}{|r|}{ Mean } & \multirow{2}{*}{$\frac{\mathrm{S}}{0.03}$} & \multirow{2}{*}{$\begin{array}{r}\text { RSD } \% \\
0.27\end{array}$} & Mean & \multirow{2}{*}{$\frac{S}{0.1}$} & \multirow{2}{*}{$\begin{array}{r}\mathrm{RSD} \% \\
0.72\end{array}$} \\
\hline Naphthalene & 10.50 & 0.09 & & & $12.15 \pm 0.10$ & & \\
\hline Acenaphthylene & 2.60 & 0.61 & 0.2 & 8.1 & $2.1 \pm 0.7$ & 0.7 & 32.8 \\
\hline Acenaphthene & 10.20 & 0.61 & 0.2 & 2.0 & $8.6 \pm 0.5$ & 0.4 & 4.9 \\
\hline Fluorene & 21.80 & 2.74 & 0.9 & 4.0 & $29 \pm 4$ & 4 & 13 \\
\hline Phenanthrene & 14.20 & 2.73 & 0.9 & 6.1 & \pm 2 & 2 & 12 \\
\hline Anthracene & 328 & 6 & 2 & 1 & \pm 53 & 53 & 16 \\
\hline Fluoranthene & 27 & \pm & 2 & 9 & \pm 2 & 2 & 9 \\
\hline Pyrene & 21 & \pm 6 & 2 & 9 & \pm 2 & 2 & 10 \\
\hline Benzo(a)anthracene & 56 & \pm 30 & 10 & 17 & $50.3 \pm 1.2$ & 1.2 & 2.3 \\
\hline Chrysene & 50 & \pm 12 & 4 & 7 & $198 \pm 11$ & 11 & 6 \\
\hline Benzo(b)fluoranthene & 78 & \pm 9 & 3 & 4 & \pm 3 & 3 & 8 \\
\hline Benzo(k)fuoranthene & 166 & \pm & 2 & 1 & \pm 20 & 20 & 12 \\
\hline Benzo(a)pyrene & 101 & \pm & 3 & 1 & $45 \pm 4$ & 4 & 8 \\
\hline Indeno(1,2,3-cd)pyrene & 38.4 & $\pm \quad 0.6$ & 0.2 & 0.4 & $20.0 \pm 1.2$ & 1.2 & 6.2 \\
\hline Dibenzo(a,h)anthracene & & n.d. & n.d & n.d. & n.d. & n.d. & n.d. \\
\hline Benzo(g,h,i)perylene & 515 & \pm 130 & 43 & 8 & \pm 3 & 3 & 2 \\
\hline Total PAH & & 1440 & 63 & 4 & 1179 & 58 & 5 \\
\hline
\end{tabular}

n.d. $=$ not detected

TABLE VIII. CERTIFIED VALUES, FOUND CONCENTRATIONS (mg/Kg) AND RECOVERIES FOR PAHs IN REFERENCE SOIL SAMPLE CRN 104-100 BY GC-MS AFTER SOXHLET AND MASE EXTRACTION

\begin{tabular}{lcccccc}
\hline PAH & \multicolumn{3}{c}{ Concentration $(\mathrm{mg} / \mathrm{Kg})$} & & \multicolumn{2}{c}{ Recovery $(\%)$} \\
\cline { 2 - 3 } \cline { 6 - 7 } & Certified Value & Soxhlet $(\mathrm{n}=3)$ & MASE $(\mathrm{n}=3)$ & & Soxlet $(\mathrm{n}=3)$ & MASE $(\mathrm{n}=3)$ \\
\hline Naphthalene & $0.77 \pm 0.18$ & $0.78 \pm 0.04$ & $0.70 \pm 0.06$ & & $101 \pm 3$ & $91 \pm 3$ \\
Acenaphthylene & $1.21 \pm 0.39$ & $1.18 \pm 0.01$ & $1.08 \pm 0.05$ & & $97 \pm 1$ & $89 \pm 1$ \\
Acenaphthene & $0.77 \pm 0.10$ & $0.71 \pm 0.02$ & $0.53 \pm 0.09$ & & $92 \pm 2$ & $69 \pm 4$ \\
Fluorene & $0.65 \pm 0.09$ & $0.62 \pm 0.01$ & $0.48 \pm 0.12$ & & $96 \pm 1$ & $73 \pm 2$ \\
Phenanthrene & $5.79 \pm 0.86$ & $6.32 \pm 0.10$ & $5.33 \pm 0.03$ & & $109 \pm 2$ & $92 \pm 1$ \\
Anthracene & $1.44 \pm 0.29$ & $1.52 \pm 0.01$ & $0.70 \pm 0.09$ & & $105 \pm 3$ & $48 \pm 3$ \\
Fluoranthene & $24.8 \pm 4.34$ & $36.6 \pm 3.0$ & $27.5 \pm 0.05$ & & $147 \pm 8$ & $111 \pm 4$ \\
Pyrene & $15.0 \pm 3.41$ & $16.5 \pm 0.01$ & $15.5 \pm 0.08$ & & $110 \pm 2$ & $103 \pm 6$ \\
Benzo(a)anthracene & $7.98 \pm 1.30$ & $9.50 \pm 0.10$ & $9.27 \pm 0.11$ & & $118 \pm 1$ & $116 \pm 4$ \\
Chrysene & $8.60 \pm 1.11$ & $9.06 \pm 0.01$ & $8.26 \pm 0.14$ & & $105 \pm 2$ & $96 \pm 3$ \\
Benzo(b+k)fluoranthene & $14.79 *$ & $11.37 \pm 0.30$ & $7.69 \pm 0.20$ & & $77 \pm 3$ & $52 \pm 4$ \\
Benzo(a)pyrene & $5.09 \pm 0.77$ & $5.45 \pm 0.90$ & $3.56 \pm 0.16$ & & $107 \pm 1$ & $70 \pm 3$ \\
Indeno(1,2,3-cd)pyrene & $4.46 \pm 1.01$ & $5.02 \pm 0.90$ & $4.09 \pm 0.10$ & & $113 \pm 1$ & $92 \pm 2$ \\
Dibenzo(a,h)anthracene & $1.55 *$ & $1.7 \pm 0.2$ & $1.17 \pm 0.14$ & & $111 \pm 2$ & $75 \pm 1$ \\
Benzo(g,h,i)perylene & $3.58 \pm 0.98$ & $4.45 \pm 0.47$ & $3.52 \pm 0.39$ & & $124 \pm 4$ & $98 \pm 3$ \\
Total PAH & 94.73 & 110.68 & 89.36 & & 117 & 94 \\
\hline
\end{tabular}

*Recommended value 


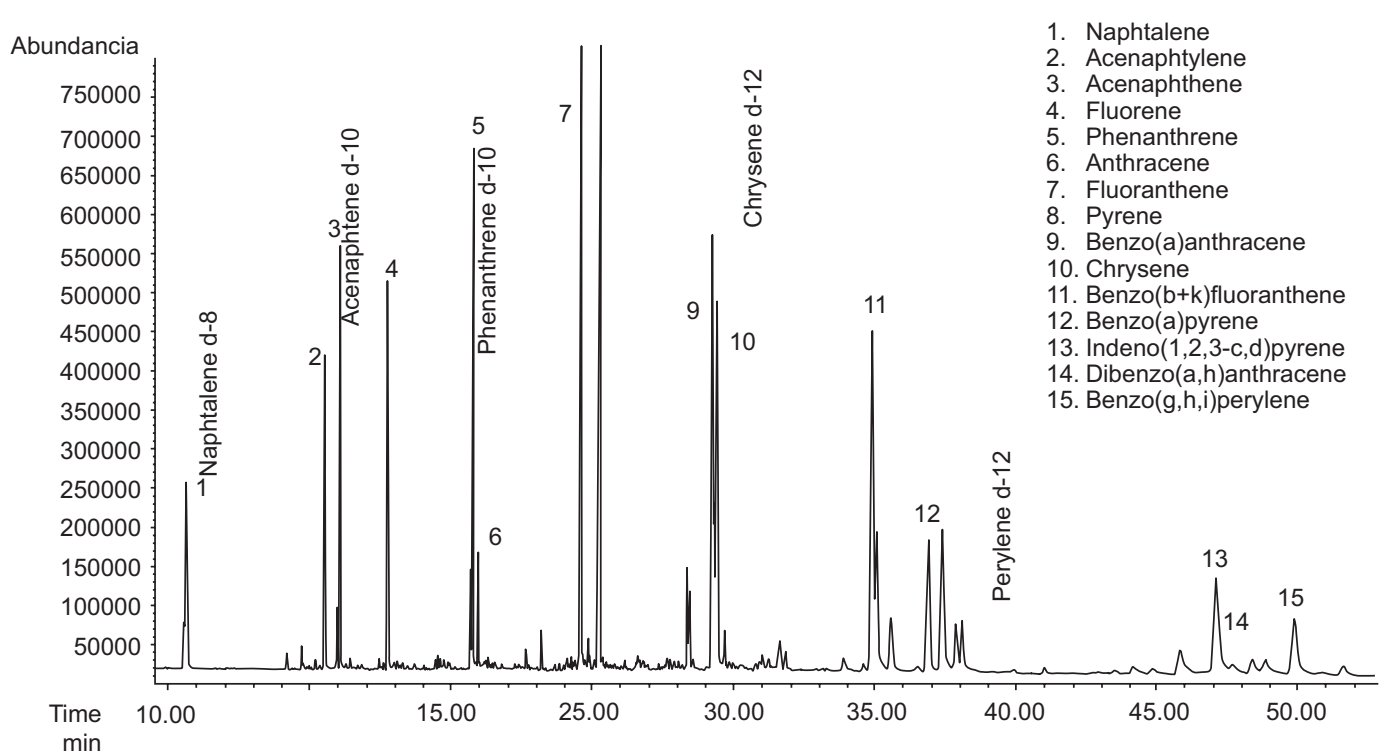

Fig. 1. Chromatogram from the CRM 104-100 soil extract after Microwave Assisted System Extraction (Dilution 1:10)

extracts, clearly reveals that such determination in soil by sample preparation and pre-concentration is reliable. Finally, good recoveries (over $70 \%$ ) were attained for the vast majority of PAHs scrutinized (except for anthracene and benzo(b+k)fluoranthene), and the repeatability is also satisfactory when calibrations were done by using internal standards.

\section{ACKNOWLEDGMENTS}

The authors thank FICYT (Asturias, Spain) for the financial support under the framework of the Project Ref. PC-CIS01-20. We also thank E. Fernández (from Cogersa, Asturias, Spain) for the assistance provided during the realization of this work.

\section{REFERENCES}

Andersson T., Hartonen K., Hyötiläinin T. and Riekkola M.L. (2002). Pressurised hot water extraction and thermal desorption of polycyclic aromatic hydrocarbons from sediment with use of a novel extraction vessel. Anal. Chim. Acta 466, 93-97. DOI: 10.1016/S0003-2670(02)00543-3

Barnabas I.J., Dean J.R., Fowlin I.A. and Owen S.P. (1995). Extraction of polycyclic aromatic hydrocarbons from highly contaminated soils using microwave energy Analyst 120, 1897-1901.

DOI: $10.1039 / A N 9952001897$
Budzinski H., Letellier M., Garrigues P. and Le Menach K. (1999). Optimisation of the microwave-assisted extraction in open cell of polycyclic aromatic hydrocarbons from soils and sediments: Study of moisture effect. J. Chromatogr. A 837, 187-192.

DOI: $10.1016 / \mathrm{S} 0021-9673(99) 00067-9$

Bouzige M., Pichon V. and Hennion M.C. (1999). Classselective immunosorbent for trace-level determination of polycyclic aromatic hydrocarbons in complex sample matrices, used in off-line procedure or on-line coupled with liquid chromatography/fluorescence and diode array detections in series. Environ. Sci. Technol. 33, 1916-1921.

DOI: $10.1021 / \mathrm{es} 9810311$

Cejpec K., Hajslovà J., Jehlickovà Z. and Merhaut J. (1995). Simplified extraction and cleanup procedure for the determination of PAHs in fatty and protein-rich matrices. Int. J. Environ. Anal. Chem. 61, 65-69.

DOI: $10.1080 / 03067319508026237$

Chee K.K., Wong M.K. and Lee H.K. (1996). Optimization of microwave-assisted solvent extraction of polycyclic aromatic hydrocarbons in marine sediments using a microwave extraction system with high-performance liquid chromatography-fluorescence detection and gas chromatography-mass spectrometry. J. Chromatogr. A 723, 259-265.

DOI: $10.1016 / 0021-9673(95) 00882-9$

Ganzler K., Salgo A. and Valko K. J. (1986). Microwave extraction : A novel sample preparation method for chromatography. J. Chromatogr. A 371, 299-305.

DOI: 10.1016/S0021-9673(01)94714-4 
Lara-Gonzalo A. (2015). Análisis forense ambiental de la contaminación multicomponente de un terreno industrial abandonado. Ph.D. thesis. Universidad de Oviedo, 178-179.

Letellier M. and Budzinski H. (1999a). Microwave assisted extraction of organic compounds. Analusis 27, 259-263. DOI: 10.1051/analusis:1999116

Letellier M. and Budzinski H. (1999b). Influence of sediment grain size on the efficiency of focused microwave extraction of polycyclic aromatic hydrocarbons. Analyst 124, 5-11. DOI: 10.1039/A807482H

Librando V., Hutzinger O., Tringali G. and Aresta M. (2004). Supercritical fluid extraction of polycyclic aromatic hydrocarbons from marine sediments and soil samples. Chemosphere 54, 1189-1191.

DOI: 10.1016/j.chemosphere.2003.07.008

Long G.L. and Winefordner J.D. (1983). Limit of detection. A closer look at the IUPAC definition. Anal. Chem. 55, 712-724. DOI: 10.1021/ac00258a001

López-Ávila V., Young R. and Beckert W.F. (1994). Microwave-assisted extraction of organic compounds from standard reference soils and sediments. Anal. Chem. 66, 1097-1102. DOI: 10.1021/ac00079a027

Mahafley W.R., Gibson D.T. and Cernighia C.E. (1988). Bacterial oxidation of chemical carcinogens: formation of polycyclic aromatic acids from benz[a]anthracene. Appl. Environ. Microb. 54, 2415-2418.

Manoli E. and Samara C. (1999). Polycyclic aromatic hydrocarbons in natural waters: sources, occurrence and analysis. TRAC-Trend. Anal. Chem. 18, 417-423. DOI: 10.1016/S0165-9936(99)00111-9

Menzie C.A., Potcki B.B. and Santodonato J. J. (1992). Exposure to carcinogenic PAHs in the environment. Environ. Sci. Technol. 26, 1278-1284.

DOI: $10.1021 / \mathrm{es} 00031 \mathrm{a} 002$

Moore S.W. and Ramamoorthy A. (1994). Organic chemicals in natural waters - Applied monitoring and impact assessment. Springer Verlag, N.Y., 292 pp.

DOI: $10.1007 / 978-1-4613-9538-6$

Pino V., Ayala J. H., Afonso A.M. and González V. (2001). Ultrasonic micellar extraction of polycyclic aromatic hydrocarbons from marine sediments. Talanta 54, 1522. DOI: 10.1016/S0039-9140(00)00622-6
Popp P., Keil P., Moder M., Paschke A. and Thuss U.J. (1997). Application of accelerated solvent extraction followed by gas chromatography, high-performance liquid chromatography and gas chromatography-mass spectrometry for the determination of polycyclic aromatic hydrocarbons, chlorinated pesticides and polychlorinated dibenzo-p-dioxins and dibenzofurans in solid wastes. J. Chromatogr. A 774, 203-207. DOI: 10.1016/S0021-9673(97)00337-3

Richer B.E., Jones B.A., Ezzell J.L. and Poter N.L. (1996). Accelerated solvent extraction: A technique for sample preparation. Anal. Chem. 68, 1033-1038. DOI: $10.1021 /$ ac9508199

Saim N. Dean J.R., Abdullah M.P. and Zakaria Z. (1997). Extraction of polycyclic aromatic hydrocarbons from contaminated soil using Soxhlet extraction, pressurised and atmospheric microwave-assisted extraction, supercritical fluid extraction and accelerated solvent extraction. J. Chromatogr. A 791, 361-366. DOI: 10.1016/S0021-9673(97)00768-1

Schantz M.M., Nichols J.J. and Wise S.A. (1997). Evaluation of pressurized fluid extraction for the extraction of environmental matrix reference materials. Anal. Chem. 69, 4210-4213.

DOI: $10.1021 / \mathrm{ac} 970299 \mathrm{c}$

Song Y.F., Jing X., Fleischmann S. and Wilke B.M. (2002). Comparative study of extraction methods for determination of PAHs from contaminated soils and sediments. Chemosphere 48, 993-1001.

USEPA (1986). Method 8100. Determination of polycyclic aromatic hydrocarbons in soil waste by gas chromatography. US Environmental Protection Agency, Washington DC.

USEPA (1995). Test Methods for evaluating solid waste. Method 3540 C. Soxhlet extraction. Washington DC.

Wild S.R and Jones K.C. (1995). Polynuclear aromatic hydrocarbons in the United Kingdom environment: A preliminary source inventory and budget. Environ. Pollut. 88, 91-95.

DOI: 10.1016/0269-7491(95)91052-M 